\title{
PELATIHAN UKM DALAM UPAYA MENGEMBANGKAN IDE-IDE KREATIF DAN INOVATIF
}

\author{
${ }^{1}$ Fitriani Latief, ${ }^{2}$ Muhammad Hidayat dan 3Dirwan \\ ${ }_{2}^{1}$ STIE Nobel Indenesia Makassar, fitri@stienobel-indonesia.ac.id \\ ${ }_{3}^{2}$ STIE Nobel Indenesia Makassar, fitri@ stienobel-indonesia.ac.id \\ ${ }^{3}$ STIE Nobel Indenesia Makassar, dirwan@stienobel-indonesia.ac.id
}

\section{Article history}

Received: 12 Agustus 2021

Revised: 28 September 2021

Accepted: 04 Oktober 2021

\section{Corresponding}

Author:

Fitriani Latief

STIE Nobel Indonesia

Makassar, Indonesia

Email: fitri@stienobel-

indonesia.ac.id

\section{Abstrak}

Merebaknya COVID-19 berimbas pada perekonomian masyarakat tidak terkecuali pada Desa Garanta di Kecamatan Ujungloe Kabupaten Bulukumba. Terlebih kegiatan perekonomian masyarakat Desa ini masih memiliki banyak kendala diantaranya adalah mental wirausaha yang masih lemah, ketidakjelasan usaha, dan kebiasaan masyarakat yang cenderung mengabaikan kualitas termasuk cara-cara pemasaran produk yang masih tradisional. Tujuan penelitian ini adalah untuk memberikan pendampingan kepada Masyarakat agar dapat mengembangkan ide-ide Kreatif dan inovatif serta menumbuhkan minat dan motivasi wirausaha yang akan menjadi modal dalam mempertahankan serta mengembangkan usaha khususnya pada masa new normal saat ini. Metode yang digunakan dalam melaksanakan kegiatan ini adalah dengan melakukan seminar, diskusi dan pelatihan atau workshop. Dari kegiatan penelitian ini masyarakat sudah mendapatkan pemahaman tentang bagaimana meningkatkan kualitas produksi dengan memperhatikan daya kreasi dan inovasi terutama dalam pengembangan variasi produk serta packaging produk sehingga produk yang dihasilkan tampil lebih baik sehingga siap dan layak untuk dipasarkan

Kata kunci - Ide-ide kreatif dan motivatif.

\section{Abstract}

The outbreak of COVID-19 has an impact on the community's economy, including Garanta Village in Ujungloe District, Bulukumba Regency. Moreover, the economic activities of the people of this village still have many obstacles, including a weak entrepreneurial mentality, business ambiguity, and people's habits that tend to ignore quality, including traditional product marketing methods. The purpose of this study is to provide assistance to the community so that they can develop creative and innovative ideas and foster entrepreneurial interest and motivation which will become capital in maintaining and developing businesses, especially during the current new normal. The method used in carrying out this activity is to conduct seminars, discussions and training or workshops. From this research activity, the community has gained an understanding of how to improve the quality of production by paying attention to the power of creativity and innovation, especially in the development of product variations and product packaging so that the resulting product looks better so that it is ready and worthy to be marketed

Keyword : Craetive idea, Innovative

\section{PENDAHULUAN}

Saat ini masyarakat sedang dihadapkan dengan adanya virus Covid 19 yang melumpuhkan perekonomian di Indonesia (Mutmainah, 2021). Salah satu dampak Pandemi COVID-19 yang signifikan dirasakan di Indonesia salah satunya adalah peningkatan pengangguran. Menurut Menteri Ketenagakerjaan Ida Fauziah kondisi ketenagakerjaan pada
Agustus 2020 menunjukkan jumlah Angkatan kerja sebesar 138,22 juta penduduk, yang bekerja sebesar 128,45 juta penduduk. Terdapat presentasi $92,93 \%$ hingga 9,77 juta orang atau naik sebesar $7,7 \% \quad$ (Sumber: https://www.cnbcindonesia.com/news/2020).

Tingginya angka pengangguran ini, menyebabkan persaingan para pencari kerja di era globalisasi semakin meningkat, semua orang 
mencari peluang pendapatan. Oleh karena itu kita tidak bisa tergantung kepada pemerintah, tapi hendaknya ada keinginan untuk berwirausaha. Salah satu cara berwirausaha adalah terlebih dahulu kita harus mempunyai jiwa berwirausaha dan mempunyai motivasi untuk berwirausaha (Rahmawati, 2013).

Salah satu cara untuk meningkatkan jumlah usaha adalah dengan meningkatkan sektor kewirausahaan, sehingga muncul pengusahapengusaha baru yang potensial dan handal. Kewirausahaan adalah suatu tindakan kreatif dalam memanfaatkan kesempatan untuk mengawaili dan menjalankan suatu kegiatan tertentu dengan tujuan memberikan pelayanan terbaik kepada pelanggan dan pihak lain (Hidayat \& Citra, 2020). Menjadi wirausaha berarti memiliki kemampuan menemukan dan mengevaluasi peluang-peluang, mengumpulkan sumberdaya yang diperlukan dan bertindak untuk mendapatkan keuntungan dari peluang tersebut.

Usaha Kecil dan Menengah (UKM) di Indonesia adalah bisnis komunitas utama dalam kegiatan ekonomi. Mereka dipercepat dalam pengembangan ekonomi masyarakat. Bisnis mikro kecil telah terbukti dapat diandalkan sebagai bisnis perlindungan dalam periode krisis, melalui mekanisme untuk penciptaan lapangan kerja dan memungkinkan Dipasihkan pendapatan negara dalam bentuk pajak.

Peran dan fungsi strategis ini sebenarnya dapat ditingkatkan dengan memainkan UKM sebagai salah satu pelaku bisnis pelengkap untuk pengembangan ekonomi nasional (Christiana et al., 2014). UKM hari ini adalah potensi bisnis yang sangat didorong oleh pemerintah Indonesia, Semakin banyak pengusaha adalah pengusaha, semakin baik dan kokoh ekonomi negara. Dengan adanya UKM sumber daya lokal, pekerja lokal, dan pembiayaan lokal dapat diserap dan bermanfaat secara optimal (Hendrawan et al., 2019). Agar UMKM dapat menjadi pilar ekonomi seperti yang diharapkan maka peningkatan komptetensi kewirausahaan bagi para pelaku UMKM mutlak untuk dilaksanakan (Hidayat \& Echdar ,2018) hal tersebut juga dikuatkan kembali yang sama juga diungkapkan kembali oleh Hidayat\& Citra (2018) yang membuktikan jika kompetensi kewirausahaan menjadi factor yang berpengaruh positif dan signifikan terhadap Kinerja wirausaha.

Desa Garanta salah satu desa yang unik perkampungannya di Kecamatan Ujungloe Kabupaten Bulukumba yang memiliki bermacam- macam nama kampung yang diambil dari kisah atau logat masyarakat yang bermukim di desa Garanta. Desa Garanta memiliki luas wilayah 9 Km. Desa Garanta terletak antara 5 derajat hingga 6 derajat lintang selatan dan melingkari meridian 120 derajat bujur timur, Jarak transportasi darat dari Kota Bulukumba sekitar $15 \mathrm{Km}$.

Desa Garanta salah satu desa yang memiliki lahan persawahan dan perkebunan yang luas di Kecamatan Ujungloe, selain itu Desa Garanta menjadi pusat pengambilan sayur para pedagang antar pasar yang ada di Kecamatan Ujungloe.

Makanan pokok masyarakat garanta adalah padi dan jagung, akan tetapi kebutuhan utama masyarakat garanta adalah padi, sedangkan jagung adalah makan pengganti padi ketika musim panen padi terlambat. Dalam satu tahun masyarakat Desa Garanta bercocok tanam dua kali padi (Pare) dan satu kali jagung (Batara), dengan melihat tanda arah angin, ketika angin bergerak ketimur menandakan musim tanam padi.

Masalah yang dihadapi UKM di Desa Garanta yaitu masyarakat desa belum dapat membaca peluang pasar, masyarakat desa masih kurang kreatif dalam mengelola sumber daya yang ada, dalam memproduksi produk mereka tidak memperhatikan dari sisi bentuk, kemasan dan lain-lain, walaupun dari sisi rasa sudah ada yang layak di jual dan masyarakat desa utamanya pelaku UKM belum maksimal dalam menjalankan usaha dan mengembangkan ide-ide yang kreatif dan inovatif.

Pernyataan di atas, searah dengan penemuan (Darwanto et al., 2013) yang menemukan beberapa masalah yang dihadapi UMKM kreatif kota Semarang diantaranya masalah permodalan yang terbatas, bahan standar dan penggunaan alat-alat produksi yang sederhana, media pemasaran terbatas lantaran belum adanya pusat UMKM, tenaga kerja yang kurang terampil, \& kasus registrasi hak cipta mereka.

Hasil penelitian (Rofaida et al., 2019) menemukan bahwa perkembangan UKM dengan industri kreatif digital dihadapkan dalam beberapa kendala, antara lain merupakan tantangan pasar yaitu tantangan yang terkait menggunakan keinginan konsumen yang mempunyai kemampuan menentukan produk digital secara lebih selektif dan persaingan diantara pelaku bisnis industri kreatif digital. Kunci utama untuk memenangkan persaingan dalam industri dimana lingkungan persaingan sangat tinggi dan keinginan pasar yang selektif 
merupakan melalui taktik inovasi (Wibowo \& Arifin, 2015). Industri kreatif digital dituntut buat selalu berinovasi baik pada proses juga produk sebagai akibatnya mempunyai keunikan yang membedakan produk yang didapatkan menggunakan pesaingnya.

Secara umum isu-isu yang menjadi penghalang pertumbuhan usaha misalnya mental wirausaha yang lemah, penutupan dan ketidakjelasan usaha, cenderung mengabaikan kualitas, pemasaran produk yang masih tradisional membuat lambat dalam menanggapu perubahan kebutuhan, kemampuan beradaptasi yang buruk dan masih terbelakang secara teknologi.

Oleh karena itu, melalui pelatihan ini masyarakat memiliki kesempatan yang besar untuk memanfaatkan sumber daya yang belum dikelola dengan baik menjadi produk unggulan yang inovatif dan kreatif.

\section{METODE}

Metode yang digunakan dalam melaksanakan kegiatan ini adalah dengan melakukan diskusi pelatihan dan koordinasi terlebih dahulu kepada Bapak Desa setempat sebagai penangungjawab mitra yang dilanjutkan dengan rapat terkait pelaksanaan dan sasaran masyarakat di wilayah setempat.

Pelaksanaan pada awalnya peserta pelatihan diberikan pemahaman tentang manfaat dan pentingnya berwirausaha untuk kemajuan usaha dan kesejahteraan. Metode yang digunakan dalam pelaksanaan kegiatan pengabdian kepada masyarakat adalah pelatihan dengan cara:

1. Memberikan pelatihan kepada Pelaku UKM dan masyarakat tentang kewirausahaan.

2. Memberikan pelatihan pemasaran dan mempromosikan produk UKM.

3. Pemahaman konsep kewirausahaan, metode digunakan adalah ceramah, diskusi, dan tanya jawab.

4. Menuangkan rencana bisnis ke dalam bisnis model kanvas, metode yang digunakan adalah ceramah, demonstrasi, diskusi dan tanya jawab.

5. Kemampuan memasarkan produk dengan memanfaatkan media sosial, maka metode yang digunakan adalah ceramah, demonstrasi, diskusi dan tanya jawab.

Adapun pelaksanaan kegiatan

dilakukan dengan tahapan sebagai berikut:

1. Pada tahap awal mitra memberikan perizinan untuk melaksanakan kegiatan pengabdian masyarakat dengan menandatangani perizinan program pelatihan kewirausahan dan pemasaran.

2. Pada tahap pelaksanaan, mitra berpartisipasi dalam menyediakan sarana dan tempat pelaksanaan.

3. Pengusul melaksanakan pelatihan kewirausahaan dan pendampingan, menyiapkan materi dan bahan/alat untuk menunjang kegiatan yang akan dilakukan.

Kegiatan Pengabdian Kepada Masyarakat dengan tema Pelatihan UKM dalam upaya mengembangkan ide-ide kreatif dan inovatif di Desa Garanta Kabupaten Bulukumba telah dilaksanakan pada tanggal 10 September 2020 di Kantor Desa Garanta Kabupaten Bulukumba. Setelah pelatihan dilakukan, pendampingan tetap diberikan selama 2 minggu.

\section{HASIL DAN PEMBAHASAN}

Sesuai dengan rencana yang telah ditentukan sebelum kegiatan pelatihan. Kegiatan pengabdian masyarakat ini diawali dengan kegiatan administrasi berupa perizinan dan undangan peserta. Peserta pelatihan ini adalah peserta dan masyarakat usaha kecil, menengah dan mikro. Kegiatan pengabdian ini diselenggarakan oleh STIE Nobel Indonesia bekerjasama dengan Kantor Desa Garanta Kabupaten Bulukumba. Perserta acara ini adalah masyarakat UKM Desa Garanta Kabupaten Bulukumba dan aparatur Kantor Desa Garanta Kabupaten Bulukumba.

Dilihat dari hasil pelaksanaan pengabdian kepada masyarakat, peserta pelatihan merespon positif materi yang disampaikan oleh pemateri Fitriani Latief tentang kewirausahaan, kemudian pemateri berikutnya Bapak Dirwan mengenai ideide yang kreatif dan inovatif mengelola potensi desa. Kemudian materi terakhir yang banyak mendapatkan perhatian dari peserta oleh Muhammad Hidayat mengenai cara pemasaran produk yang baik ditengah pandemik Covid-19.

Dengan materi-materi yang telah diberikan membantu membangun jiwa wirausaha peserta, memahami konsep dasar kewirausahaan, peserta mampu mengetahui aspek pemasaran, produksi dan permodalan.

Kegiatan pelatihan ini tidak hanya satu arah, tetapi juga dua arah saat pelatihan dilakukan. Diskusi berjalan dengan tertib setelah penyampaian materi. Peserta diskusi berperan aktif dalam bertanya dan menjawab pertanyaan yang dihadapi oleh masing-masing peserta usaha.

Dampak dan manfaat kegiatan pengabdian 
masyarakat dapat mengetahui ide-ide kreatif dan inovatif produk dalam beriwirausaha.

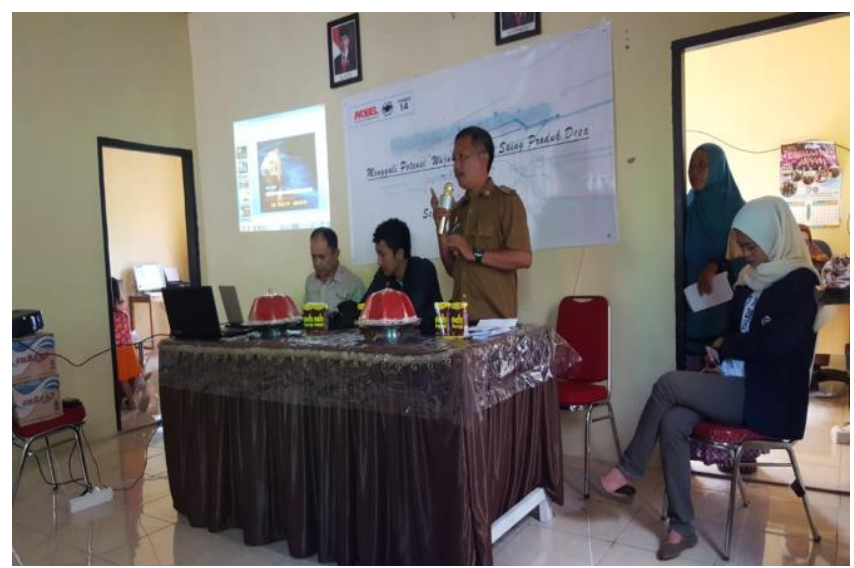

Gambar 1. Pemateri

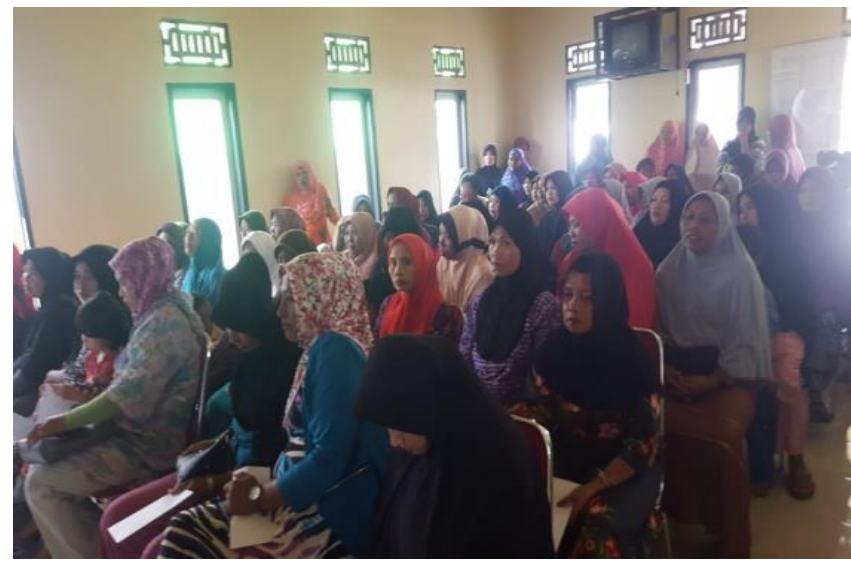

Gambar 2. Peserta Kegiatan

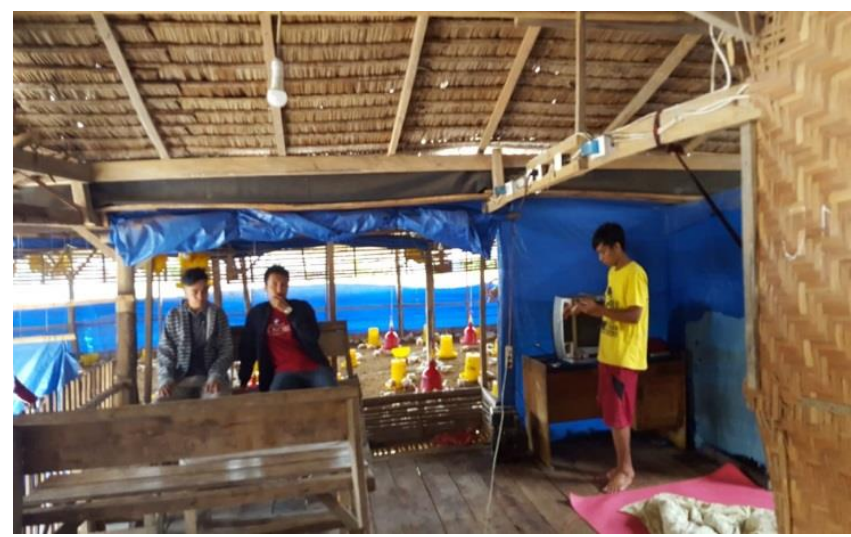

Gambar 3. Observasi Kegiatan Masyarakat

\section{KESIMPULAN}

Berdasarkan hasil kegiatan yang telah dilakukan terdapat poin-poin sebagai berikut :

1. Pengetahuan dan pemahaman pelaku usaha berkaitan dengan semangat kewirausahaan.

2. Pelatihan yang dilakukan dapat meningkatkan jiwa wirausaha dan semangat kerja pelaku usaha dalam menjalankan kegiatan usaha yang benar dan optimal.

3. Hasil kegiatan pelatihan pengabdian masyarakat menunjukkan pelatihan kewirausahaan ada pada setiap peserta dan membuat semangat bisnis mereka lebih baik.

\section{SARAN}

Masyarakat diharapkan mendiskusikan lebih lanjut tentang bisnis mereka dan mampu memberikan nilai jual tinggi dan sanggup menaikkan kualitas perekonomian warga Desa Garanta Kabupaten Bulukumba.

\section{DAFTAR PUSTAKA}

Christiana, Y., Pradhanawati, A., \& Hidayat, W. (2014). Pengaruh Kompetensi Wirausaha, Pembinaan Usaha dan Inovasi Produk Terhadap Perkembangan Usaha (Studi Pada Usaha Kecil dan Menengah Batik di Sentra Pesindon Kota Pekalongan). Jurnal Ilmu Administrasi Bisnis, 3(4), 384-393.

Darwanto, D., Tri, U., \& Danuar, D. (2013). Pengembangan Usaha Mikro Kecil dan Menengah (UMKM) Berbasis Ekonomi Kreatif di Kota Semarang. Diponegoro Journal of Economics, 2(4), 19599.

Hendrawan, A., Kuswantoro, F., \& Sucahyawati, H. (2019). Dimensi Kreativitas dan Pengembangan Usaha Mikro Kecil dan Menengah (UMKM). Jurnal HUMMANSI (Humaniora, Manajemen, Akuntansi), 2(1).

Hidayat, M., \& Citra, C. (2020). PENGARUH KOMPETENSI KEWIRAUSAHAAN, ORIENTASI PASAR DAN MOTIVASI BERWIRAUSAHA TERHADAP KINERJA BISNIS WARUNG KOPI DI KOTA MAKASSAR. Jurnal Mirai Management, 5(1), 244-256.

Mutmainah, I. (2021). Strategi Pemasaran UMKM KUB Berkah di Desa Karang Asem pada Era New Normal. Jurnal Ilmu Ekonomi Dan Bisnis Islam, 3(1), 97-105.

Rahmawati, D. (2013). Motivasi Entrepreneurship Pada Mahasiswa Jurusan Manajemen Pendidikan. Perspektif Ilmu Pendidikan, 27(1), 1-7.

Rofaida, R., Aryanti, A. N., \& Perdana, Y. (2019). Strategi Inovasi pada Industri Kreatif Digital: Upaya Memperoleh Keunggulan Bersaing pada Era Revolusi Industri 4.0. Jurnal Manajemen Dan Keuangan, 8(3), 402-414.

Wibowo, D. H., \& Arifin, Z. (2015). Analisis strategi pemasaran untuk meningkatkan daya saing UMKM (Studi pada Batik Diajeng Solo). Jurnal Administrasi Bisnis, 29(1), 5966.

Hidayat, M., Latief, F., Nianti, D. A., Bahasoan, S., \& 
Widiawati, A. (2020). Factors influencing Hidayat, M., \& Echdar, S. (2018). The Influence resilience of micro small and medium entrepreneur (MSME) during COVID 19 outbreak in South Sulawesi Province Indonesia.

Of Farmer Entrepreneurship Organizational Competence On Cacao Productivity. 